\title{
Donor Cell Leukemia in a Patient Developing 11 Months after an Allogeneic Bone Marrow Transplantation for Chronic Myeloid Leukemia
}

\author{
Selmin Ataergin, ${ }^{1}$ Fikret Arpaci, ${ }^{1 *}$ Turker Cetin, ${ }^{2}$ Sefik Guran, ${ }^{3}$ \\ Cengiz Yakicier, ${ }^{3}$ Murat Beyzadeoglu, ${ }^{4}$ and Ahmet Ozet ${ }^{1}$ \\ ${ }^{1}$ Department of Medical Oncology and Bone Marrow Transplantation Unit, Gulhane Faculty of Medicine, Ankara, Turkey \\ ${ }^{2}$ Department of Hematology, Gulhane Faculty of Medicine, Ankara, Turkey \\ ${ }^{3}$ Department of Molecular Biology, Gulhane Faculty of Medicine, Ankara, Turkey \\ ${ }^{4}$ Department of Radiation Oncology, Gulhane Faculty of Medicine, Ankara, Turkey
}

\begin{abstract}
A 38-year-old female with chronic myeloid leukemia underwent an allogeneic bone marrow transplantation from her full-matched brother. Eleven months later, she readmitted with an acute leukemia that was shown to be of donor origin. The patient never achieved a remission even after chemotherapies with cytarabine and mitoxantrone, donor lymphocyte infusion, and second allogeneic peripheral blood stem cell transplantation. Donor cell leukemia (DCL) is sometimes misdiagnosed as relapse by clinicians and the real incidence may be higher than expected. Cytogenetic and molecular techniques may be helpful to clarify the issue of the leukemia. The current case is another case of DCL reported in the literature after an allogeneic transplant for a kind of leukemia. Am. J. Hematol. 81:370-373, 2006 (ㄷ) 2006 Wiley-Liss, Inc.
\end{abstract}

Key words: leukemia; CML; donor cell; bone marrow transplantation; TBI

Donor cell leukemia (DCL) is a very rare event. Although Boyd et al. suggested that DCL accounted for approximately $5 \%$ of relapses on the basis of cytogenetic studies of 54 relapses in sex-mismatched bone marrow transplants [1], in an EBMT survey, the occurrence rate is reported as 14 cases in 10,489 transplants between 1982 and 2003 [2]. Several hypotheses have been offered to date to explain how DCL might arise: occult leukemia in the donor [3], transfer of oncogenic material from host to donor cells [4], impaired immune surveillance [5], incorrect identification of origin of leukemic cells, or leukemic transformation of engrafted bone marrow cells $[6,7]$.

We describe a case of DCL manifested 11 months after an allogeneic bone marrow transplantation (BMT). Ph chromosome positive chronic myeloid leukemia $(\mathrm{CML})$ was diagnosed by cytogenetic analysis in a 38-year-old woman. She was initially treated with hydroxyurea and IFN- $\alpha$ until the achievement of hematological but not cytogenetic remission. Sixteen months later, she underwent allogeneic BMT from her HLA-identical brother after a conditioning regimen with total body irradiation and cyclophosphamide. The donor was healthy at the time of bone marrow harvest with a normal marrow examination. Cyclosporine and methothrexate were used for prophylaxis of graft-versus-host disease (GVHD). Successful engraftment was achieved without GVHD after BMT. Ph chromosome was negative in all 30 metaphases. Six months after BMT, full donor origin chimerism $(46, \mathrm{XY})$ and a negative $\mathrm{BCR} / \mathrm{ABL}$ result by FISH were noted. Eleven months later, she presented with weakness, widespread bone pain, and abnormal complete blood count with a hemoglobin level of $10 \mathrm{~g} / \mathrm{dl}$, a white blood cell count of $15 \times 10^{9} / \mathrm{L}$, and a platelet count of $83 \times 10^{9} / \mathrm{L}$. There were $30 \%$ blastic cells with myeloid nature in the blood smear. Bone marrow biopsy

*Correspondence to: Fikret Arpaci, Gulhane Faculty of Medecine, Department of Medical Oncology and BMT Unit, 06010 Etlik, Ankara, Turkey.

E-mail: farpaci@gata.edu.tr; sataergin@superonline.com

Received for publication 25 October 2005; Accepted 15 November 2005

Published online in Wiley InterScience (www.interscience.wiley.com). DOI: $10.1002 /$ ajh.20615 


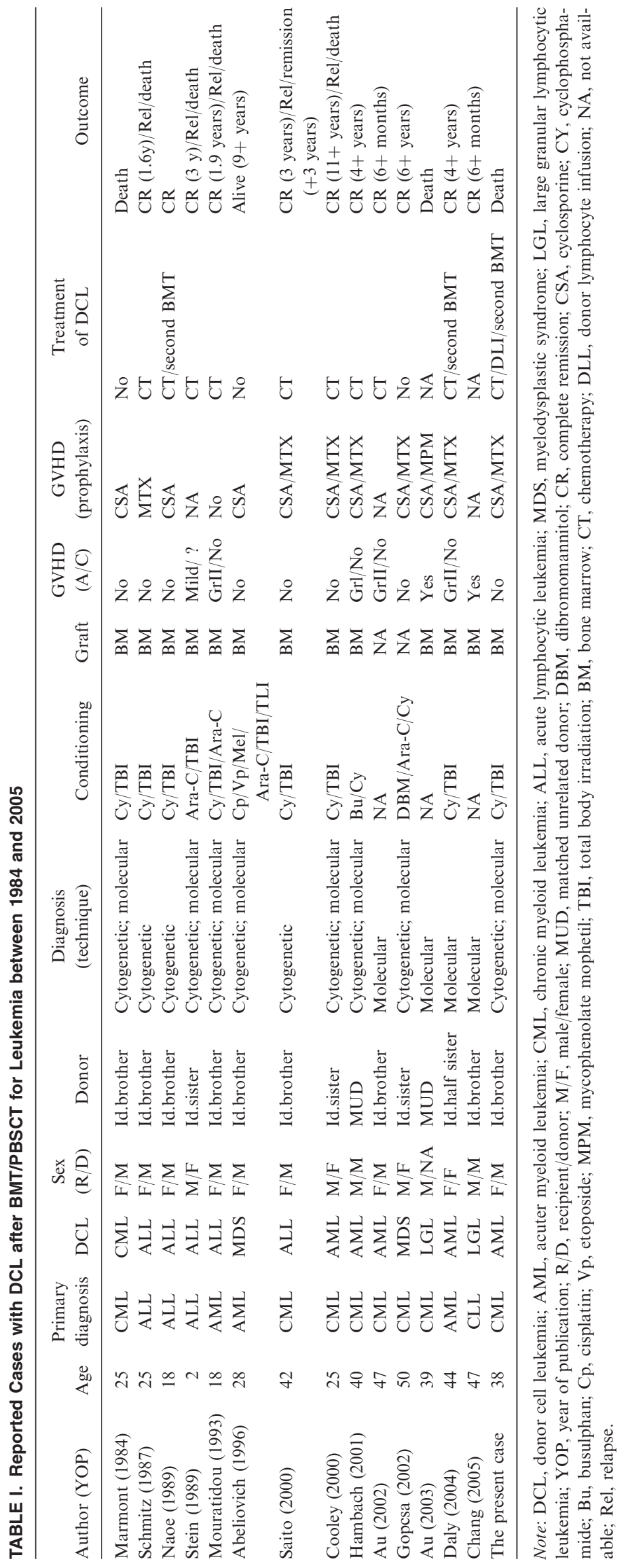


showed diffuse infiltration with blasts that were positive for peroxydase, but negative for esterase and PAS. Flow-cytometric analysis revealed that the blasts were positive for CD13, CD33, CD11b, CD11c, and CD15. Acute myeloblastic leukemia was diagnosed. The karyotypic analysis of the marrow by $\mathrm{Y}$ chromosome amplification revealed 46, XY karyotype in all 20 metaphases. No evidence for fusion of BCR and $\mathrm{ABL}$ was noted by RT-PCR. The leukemia was therefore donor origin. Peripheral blood and bone marrow examination of the donor were normal and no hematological abnormalities were noted up to the last 7-year follow-up. Induction chemotherapy with high-dose cytarabine and mitoxantrone were initiated, but hematologic remission was not achieved. Donor lymphocyte infusion (DLI) was done in two fractions 20 days apart. The patient failed to respond to DLI and 18 months after the first transplantation, a nonmyeloablative allogeneic peripheral stem cell transplantation was performed from her second brother with HLA two-antigen mismatched. However, the patient died on day +12 posttransplant. Postmortem bone marrow and liver biopsy examination showed widespread infiltration with blasts.

We identified 15 cases of DCL after BMT for a type of leukemia by a MEDLINE search of the English language literature from 1984 through 2005 (Table 1).

The simplest way to detect the origin of a clone is the demonstration of the opposite sex in the leukemic cells in sex-mismatched BMT recipients by conventional cytogenetic analysis or T-cell chimerism from either donor or recipient [8,9]. EBMT survey emphasizes that (1) the diagnosis of DCL was based on sexmismatch in 6/14 cases. We showed $\mathrm{Y}$ chromosome in all metaphases by $\mathrm{Y}$ chromosome amplification; (2) the median age of patients developing DCL was 27 years old (range, 12-56) at transplant and the occurrence of DCL was at a median of 17 months (range, 4-164). Our case falls in these ranges; (3) no type of conditioning, donor, graft manipulation, GVHD prophylaxis, or subsequent complications was identified as a risk factor for the development of DCL and none of the stem cell donors developed hematological malignancies on a median follow-up of 9 years. In this survey, a bone marrow examination was performed in three of the donors and an additional cytogenetic analysis was carried out in one patient. We observed no hematologic or solid organ malignancy in our donor during follow-up; (4) chemotherapy may induce remission in DCL and only two of five patients were reported to be alive after a second transplant. However, our patient did not achieve a remission after these treatment modalities.
Some cases of DCL are not reported or are misdiagnosed as relapse. Reporting all data about such cases may help to constitute a patient pool for better understanding the nature, prognosis, and treatment options of this rare condition.

\section{REFERENCES}

1. Boyd CN, Ramberg RC, Thomas ED. The incidence of recurrence of leukemia in donor cells after allogeneic bone marrow transplantation. Leuk Res 1982;6(6):833-837.

2. Hertenstein B, Hambach L, Bacigalupo A, et al. Chronic Leukaemia Working Party of the European Group for Blood and Marrow Transplantation. Development of leukemia in donor cells after allogeneic stem cell transplantation - a survey of the European Group for Blood and Marrow Transplantation (EBMT) Haematologica 2005;90:969-975.

3. Niederwieser DW, Appelbaum FR, Gastl G, Gersdorf E, Meister B, Geissler D, Tratkiewicz JA, Thaler J, Huber C. Inadvertent transmission of a donor's acute myeloid leukemia in bone marrow transplantation for chronic myelocytic leukemia. N Engl J Med 1990;322(25):1794-1796.

4. Thomas ED, Bryant JI, Buckner CD, Clift RA, Fefer A, Neiman P, Ramberg RE, Storb R. Leukemic transformation of engrafted human marrow. Transplant Proc 1972;4(4):567-570.

5. Cransac M, Boiron JM, Merel P, Cony-Makhoul P, Marit G, Bernard P, Ferrer J, Reiffers J. Burkitt-type acute lymphoblastic leukemia in donor cells after allogeneic bone marrow transplantation for acute nonlymphoblastic leukemia. Transplantation 1993;56(1):120.

6. Fialkow PJ, Thomas ED, Bryant JI, Neiman PE. Smith JL, Heerema NA, Provisor AJ. Leukaemic transformation of engrafted human marrow cells in vivo. Leukaemic transformation of engrafted bone marrow cells. Lancet 1971;1(7693):251-255.

7. Smith JL, Heerema NA, Provisor AJ. Leukaemic transformation of engrafted bone marrow cells. Br J Haematol 1985;60(3):415-422.

8. Stein J, Zimmerman PA, Kochera M, et al. Origin of leukemic relapse after bone marrow transplantation: comparison of cytogenetic and molecular analyses. Blood 1989;73:2033-2040.

9. Lawler SD, Baker MC, Harris H, Morgenstern GR. Cytogenetic studies on recipients of allogeneic bone marrow using the sex chromosomes as markers of cellular origin. Br J Haematol 1984;56:431443.

10. Marmont A, Frassoni F, Bacigalupo A, Podesta M, Piaggio G, Van Lint MT, Caimo A, de Filippi S. Recurrence of Ph'-positive leukemia in donor cells after marrow transplantation for chronic granulocytic leukemia. N Engl J Med 1984;310(14):903-906.

11. Schmitz N, Johannson W, Schmidt G, von der Helm K, Loffler H. Recurrence of acute lymphoblastic leukemia in donor cells after allogeneic marrow transplantation associated with a deletion of the long arm of chromosome 6. Blood 1987;70(4):109910104.

12. Naoe T, Kiyoi H, Yamanaka K, Naito K, Yamada K. A case of cALL relapse after allogeneic BMT: recurrence of recipient cell origin, initially determined as being that of donor cell origin by sex chromosome analysis. Br J Haematol 1989;73(3):420-422.

13. Stein J, Zimmerman PA, Kochera M, Strandjord S, Golden W, Simon M, Warkentin P, Blazar BR, Coccia P, Lang-Unnasch N. Origin of leukemic relapse after bone marrow transplantation: comparison of cytogenetic and molecular analyses. Blood 1989; 73(7):2033-2040.

14. Mouratidou M, Sotiropoulos D, Deremitzaki K, Spathas DH, Hoffbrand AV, Prentice HG, Papanastasiou K, Tsakanikas S, 
Tsaftaridis P, Stamatelou M, et al. Recurrence of acute leukemia in donor cells after bone marrow transplantation: documentation by in situ DNA hybridization. Bone Marrow Transplant 1993;12(1):77-80.

15. Abeliovich D, Yehuda O, Nagler A, Lerer I, Ben-Neriah S, Amar A, Or R. Predominant 45,X,--Y karyotype in donor cells after allogeneic BMT: cytogenetic and molecular analysis. Cancer Genet Cytogenet 1996;86(1):1-7.

16. Saito Y, Uzuka Y, Sakai N, Suzuki S, Toyota T. A Philadelphia chromosome positive acute lymphoblastic leukemia of donor origin after allogeneic bone marrow transplantation for chronic myelogenous leukemia in chronic phase. Bone Marrow Transplant 2000;25(11):1209-1211.

17. Cooley LD, Sears DA, Udden MM, Harrison WR, Baker KR, Donor cell leukemia: report of a case occurring 11 years after allogeneic bone marrow transplantation and review of the literature. Am J Hematol 2000;63(1):46-53.

18. Hambach L, Eder M, Dammann E, Battmer K, Stucki A, Heil G, Ganser A, Hertenstein B. Donor cell-derived acute myeloid leukemia developing 14 months after matched unrelated bone marrow transplantation for chronic myeloid leukemia. Bone Marrow Transplant 2001;28(7):705-707.
19. Au WY, Chan EC, Siu LL, Lau TC, Lie AK, Ma SK, Kwong YL. Leukaemic relapse of donor origin after allogeneic bone marrow transplantation from a donor who later developed bronchogenic carcinoma. Br J Haematol 2002;119(3):777-780.

20. Gopcsa L, Barta A, Banyai A, Konya M, Pajor L, Foldi J, Paloczi K. Acute myeloid leukaemia of donor cell origin developing 5 years after allogeneic bone marrow transplantation for chronic myeloid leukaemia. Bone Marrow Transplant 2002; 29(5):449-452.

21. Au WY, Lam CC, Lie AK, Pang A, Kwong YL. T-cell large granular lymphocyte leukemia of donor origin after allogeneic bone marrow transplantation. Am J Clin Pathol 2003;120(4): 626-630.

22. Daly AS, Kamel-Reid S, Lipton JH, Messner HA, Kiss TL, Chun K, Busque L, Chang H. Acute leukemia of donor origin arising after stem cell transplantation for acute promyelocytic leukemia Leuk Res 2004;28(10):1107-1111.

23. Chang H, Kamel-Reid S, Hussain N, Lipton J, Messner HA. T-cell large granular lymphocytic leukemia of donor origin occurring after allogeneic bone marrow transplantation for B-cell lymphoproliferative disorders. Am J Clin Pathol 2005;123(2): 196-199. 